\title{
Meadow up a tree: Feeding flocks with a native ash tree in the Moroccan mountains
}

\author{
Didier Genin', Céline Crochot ${ }^{2}$, Soufiane MSou $^{3}$, Abdelilah Araba $^{4}$ and Mohamed Alifriqui ${ }^{5,6^{*}}$
}

\begin{abstract}
The pastoral interest in Fraxinus dimorpha foliage from the High Atlas of Morocco was assessed both in terms of its role with regard to the feeding of small ruminant flocks and for its nutritive value. Observation, measurements, and interviews with 57 households revealed that ash trees are regularly pollarded, following very precise four-year cycles, during late August to November. Native ash tree stands are subject to characteristic shaping, which enables a continuous capability to provide fodder, and gives rise to characteristic sylvo-pastoral landscapes. A digestion trial was conducted in goats and sheep. Five two-year-old rams (19.5 $\pm 1 \mathrm{~kg})$ and five two-year-old uncastrated bucks $(22.2 \pm 1.7 \mathrm{~kg})$ were placed in individual metabolism cages over 18 days, and fed fresh ash tree leaves with a light dietary supplementation. The apparent digestibility coefficients between goats and sheep did not differ significantly for dry matter (69.5\% versus 67.5\%, respectively), organic matter (70.5\% vs 68.3\%), and Neutral Detergent Fibre (53.8\% vs $52.3 \%)$, in contrast to crude protein $(54.2 \%$ vs $45.3 \%, p<0.001$ ) and Acid Detergent Lignin (29.7 vs 26.4 , $p<0.05$ ). Due to a higher intake relative to metabolic weight (57.1 vs $47.7 \mathrm{gDM} / \mathrm{kgBW}^{0.75}$ ), goats valorize this type of forage better than sheep. It is concluded that ash tree foliage presents considerable nutritive interest in autumn when overall range forage is scarce and lacking in quality, and, hence, constitutes a useful forage resource for feeding the small ruminant flocks found in these low-input mountain livestock farming systems. Associated traditional management practices were revealed to be both technically and ecologically efficient, and should be better taken into account by policy-makers.
\end{abstract}

Keywords: Digestibility, Fraxinus dimorpha, Local knowledge, Low-input farming systems, Morocco, Tree fodder management

\section{Background}

Trees and forests have historically played an important role for livestock feeding in most parts of the world (Charlton et al. 2003; Le Houerou 2006), and their exploitation has been traced back to Neolithic times (Thiebault 2005). In the 19th century, for example, Slotte (2001) estimated that almost nine million trees were pollarded each year in the Swedish forest to provide leaf-hay as winter diet for cattle and sheep. Another example is the practice of pollarding and coppicing trees in Great Britain over more than three centuries (Petit and Watkins 2004). Nowadays, trees and forests are still an important source of forage in low-input livestock

\footnotetext{
* Correspondence: alifriqui@gmail.com

${ }^{5}$ Department of Ecology, Université Cadi Ayyad, Faculté des sciences Semlalia, Marrakesh, Morocco

${ }^{6}$ Department Environment \& Ecology. Faculté Semlalia, Université Cadi

Ayyad, Marrakesh, Morocco

Full list of author information is available at the end of the article
}

farming systems (Le Houerou 2006). Reports from different regions emphasize the critical role of trees as a source of fodder (i.e. Etienne 1996 for the Mediterranean area in Western Europe, Paterson et al. 1998 and Faye et al. 2010 for Africa, Thapa et al. 1997 for Asia, Solorio Sanchez and Solorio Sanchez 2002 for Central America). Moreover, new environment-friendly forms of agricultural production tend to promote trees and forest patches within integrated agroforestry systems, where the ligneous component not only provides environmental benefits but can also be a valuable resource for timber, forage, non-timber forest products (NTFP), or energy (Arnold and Dewees 1997; Genin et al. 2013). However, knowledge about the use and management of these rural trees and forests has been largely lost (Petit 2003).

In Morocco, trees and forests have been and still are the pillar of several traditional farming systems. The 
most spectacular example concerns the multiple uses of the emblematic argan tree (Argania spinosa), widely known because of the famous cosmetic oil it produces, and also because of the very popular tourist attraction of goats climbing onto the top of the trees. This system has seen a very long historic trajectory of co-evolution between trees and livestock (Bourbouze and El Aïch 2005; McGregor et al. 2009). In the mountains of the High Atlas, local populations have developed highly sophisticated practices in order to manage forest resources for combined fodder and timber production (Genin and Simenel 2011). An undocumented example is given here concerning the multipurpose management of a native ash tree (Fraxinus dimorpha), which is pollarded and pruned for the production of poles and beams, but also mainly for the feeding of small ruminant flocks. As far as we know, $F$. dimorpha has not been documented in terms of its forage interest and management. In particular, no information is available on its nutritive value, or on traditional management practices.

In this article, we aimed to characterize 1) the importance of the forage resource provided by the ash tree in the traditional feeding system of small ruminant flocks in an area where this tree species dominates local forests and 2) the nutritive value of this fodder for both sheep and goats.

\section{Study area}

F. dimorpha, called imts in Berber, is a native tree species of North African and Central Asian mountains. In Morocco, it occupies a particular ecological niche, being localized in the coldest parts of the slopes and ravines of the High and Middle Atlas, where temperature inversions occur, between 1,400 and 2,000 masl. The ash tree is a multipurpose tree providing both forage (leaves and seeds when available), timber (poles, beams, and handles for tools), firewood, alimentary (component of Ras el Hanout spice) and medicinal products (seeds), and dyes. The physiognomy of ash tree stands is in the form of scattered trees (15 to 50 trees/ha), parklands or 'tree savanna', similar to that referred to by Boffa (1999), with a density ranging from 50 to 500 trees/ha, or denser forests ( $>800$ trees/ha). The regional surface area of ash tree stands has not yet been formally characterized, but the tree stands form discontinuous patches found mainly throughout the northern part of the High Atlas and in the Middle Atlas. The main characteristic of ash tree stands is that individual trees are commonly pollarded and shaped with a wide diversity of forms: overgrazed trees at ground level (locally called 'green rocks'), shrubby forms directly browsed by small stock and forming groves in the landscape, single- or multistemmed trees, and trees presenting a large trunk, as the result of the previous selection of stumps by farmers, and very sophisticated shaping practices developed to favour twig anastomosis (Genin and Alifriqui, in press) (Figure 1). These forms all correspond to the differentiated functions they have for providing diverse products for local livelihoods (Genin and Alifriqui, in press).

The study was conducted in the rural Commune of Aït M'Hamed, located in the central High Atlas, Azilal Province. Altitude ranges from 1,300 to $1,700 \mathrm{~m}$. The climate is mountain Mediterranean with annual precipitation between 450 and $600 \mathrm{~mm}$, and mean minimum temperature in winter of $5^{\circ} \mathrm{C}$, and mean maximum temperature in summer of $28^{\circ} \mathrm{C}$.

Local agropastoral systems are low-input based on rain-fed cereal cultivation, associated with small ruminant flocks of 20 to 150 heads, including variable proportions of sheep and goats. The local population are all Berber, related to the famous Ait Atta nomadic tribe, but sedentarized at the end of the 19th century. Forested areas represent about $25 \%$ of the total territory and are divided into two categories: those dominated by the holm oak (Quercus ilex) and those dominated by the dimorph ash tree, in the coldest areas. These two species also occur together to form mixed forests and parklands. Scattered ash trees are mainly found in the Lahbab plateau, near the small town of Ait M'Hamed, growing on an adverse lapiaz soil. Very refined elaborate practices of exclosure of young or overgrazed trees by means of stone walls ('tahboucht' in Berber), and of shaping and linking twigs in order to favour twig anastomosis, are sometimes employed by the local population in order to preserve and prepare them for improved forage, and pole or beam production (Genin and Alifriqui, in press).

\section{Methods}

The study design included both 1) a field survey, in order to improve knowledge on current practices in ash tree exploitation and management of flock feeding on a year-round basis, by combining observations, measurements, and discourse analysis, and 2) an assessment of the nutritive value of fresh ash tree leaves in autumn. We paid particular attention to this period because it is a critical transition period where native grasses have already been consumed or are dried up, and where ash tree leaves traditionally represent a major component of the daily diet of sheep and goats.

\section{Survey of herd feeding management practices}

We have conducted various previous informal surveys from 2011 to 2013 in order to become familiar with the farming systems under study. Fifty-seven additional formal participant observations, including both semidirected interviews and measurements, were conducted with individual farmers (mainly male family heads) by means of snowball sampling (Biernacki and Waldorf 


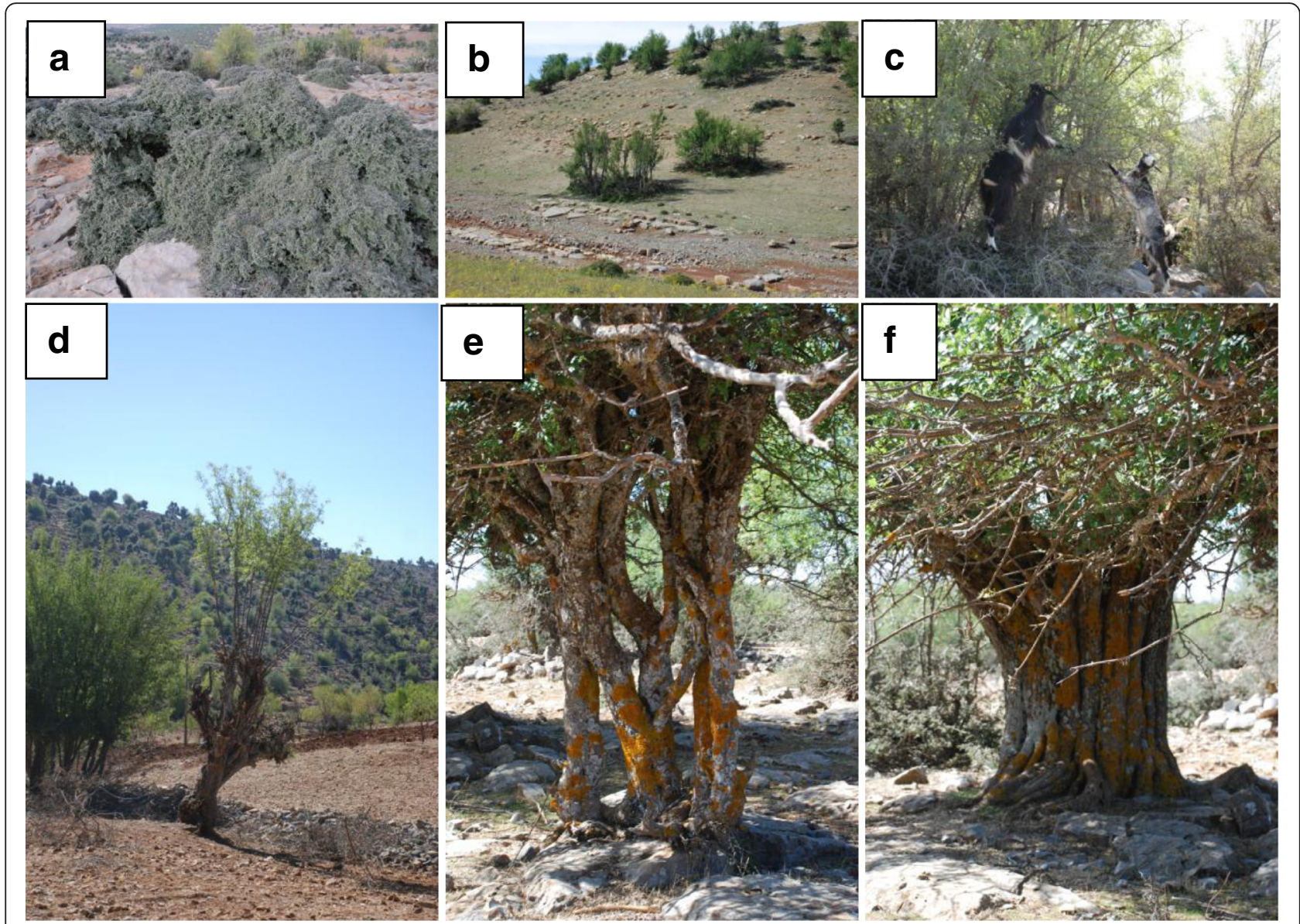

Figure 1 Different human-induced ash tree ports providing differentiated pastoral resources. (a) Overgrazed tree (locally called 'green rock'),

(b) ash trees forming small groves for browsing and livestock resting, (c) shrubby ash tree directly browsed, (d) single-stemmed pollarder ash tree, (e) multi-stemmed pollarder ash tree, and (f) pollarded ash tree with a large anastomosed trunk, resulting from practices intended to improve leaf and wood productivity

1981). They were performed from August to November 2013, aiming to assess the feeding calendar of the flocks, and to better characterize ash tree uses and management practices. Each interview was performed directly on rangelands in the Berber language in order to facilitate information transmission, and lasted between two and three hours. Data were obtained on the number of trees owned, the number of branches cut per day in relation with the size of the flock, criteria of selection for individual trees to be exploited, rotation of cuts, knowledge of the biology of the tree and its interactions with livestock feeding, practices performed for safe cutting, and overall daily diet provided to livestock. Measurements included number of poles cut per day, fresh and dry weight leaves per pole ( $n=3$ per survey), number of small stock being fed, and proportion of tree types in the stand (three $100 \times 5 \mathrm{~m}$ bands per survey), based on the morphological aspect (big anastomosed trunk, multistemmed or coppice tree, single-stemmed tree, shrubby aspect, green rock).
Assessment of the nutritive value of fresh ash tree leaves in autumn

\section{Digestion trial}

A comparative digestion trial was performed from 2828 September 2013 to 1818 October 2016. The trial was run in situ in a small pen of a traditional farm surrounded by ash tree parkland. We decided to perform this digestion trial directly under real conditions instead of at an experimental station, in order to rapidly collect fresh material and imitate as close as possible real-life features. The experiment consisted of a 10-day adjustment period followed by an 8-day faecal collection period. Five two-year-old rams $(19.5 \pm 1 \mathrm{~kg})$ and five two-year-old bucks $(22.2 \pm 1.7 \mathrm{~kg})$ were housed in individual metabolic cages. Both rams and bucks were of local breed, well-accustomed to the consumption of ash tree leaves. They were previously treated against internal and external parasites with the equivalent of Ivomec, prior to the experiment. Animals were fed fresh ash tree leaves ad libitum, hand-collected every evening from 
adult ash trees which had been previously pollarded four years ago. They were fed twice daily (8:00 and 17:00). The animals' diet was supplemented with $150 \mathrm{~g}$ of standardized concentrate composed of $770 \mathrm{~g} / \mathrm{kg}$ barley, 200 $\mathrm{g} / \mathrm{kg}$ wheat bran, and $30 \mathrm{~g} / \mathrm{kg}$ commercial mixed minerals and vitamins. This low-quantity supplement was adopted in order to mimic other forages found in the rangelands (Meuret 1988), and may prevent possible intoxication related to a single unknown tree leaf diet, as suggested by Nastis and Malechek (1981). Water was offered ad libitum. Faeces and feed residues were weighed daily, and a $10 \%$ aliquot was composited across days for each animal for further analysis.

\section{Chemical analyses}

Chemical analyses concerned both 1) the assessment of the nutrient content of ash tree leaves and their digestibility and 2) the possible presence of secondary compounds that could be suspected to have anti-nutritional and/or medicinal effects.

Feed, refusals, and faecal samples were thawed at room temperature, dried in a forced draught oven at $60^{\circ} \mathrm{C}$ for $48 \mathrm{~h}$, and ground to pass a 1-mm screen with a Wiley mill, following standard methods (AOAC 1990). Ash content was measured after igniting samples in a muffle furnace at $550^{\circ} \mathrm{C}$ for four hours. Organic matter (OM) and crude protein (CP) were analysed according to methods 934.01, 942.05, and 976.05 of AOAC (1990). Neutral Detergent Fibre (NDF) and Acid Detergent Fibre (ADF) were assayed without a heat stable amylase and expressed exclusive of residual ash, according to Van Soest et al. (1991) and method 973.18 (AOAC 1990), respectively. There was no sodium sulphite inclusion in the NDF analysis. Lignin (sa) content was determined by solubilization of cellulose with sulphuric acid, following Robertson and Van Soest (1981). Forage analyses were performed at the Animal Production Laboratory of the Hassan II Agronomy and Veterinary Institute of Rabat, Morocco. Additional preliminary secondary compound screening was also performed on leaves and seeds at the Laboratory of Phytochemistry of the University Cadi Ayyad of Marrakesh, based on precipitation and coloration reaction, in order to roughly detect the presence of different chemical groups, and following standard methods described in detail by Msou (2013). Even if leaves and seeds are not separated when fed to animals, they were separated here for analyses since they are said locally to have different properties in the local pharmacopoeia.

\section{Digestibility calculations and estimations}

The study design allows estimation of the digestibility of ash tree leaves separately from supplementary diet by subtracting digestible standardized concentrate intake from total digestible intake (Nastis and Malechek 1981; Narvaez et al. 2011). Thus, the digestibility of the various F. dimorpha nutrient components $\left(\mathrm{FD}_{\mathrm{Dig}}\right)$ was calculated as follows:

$$
\mathrm{FD}_{\text {Dig }}=\frac{\operatorname{Ing}_{\text {tot }} * \mathrm{Dig}_{\text {tot }}-\operatorname{Ing}_{\text {conc }} * \operatorname{Dig}_{\text {conc }}}{\operatorname{Ing} \mathrm{FD}}
$$

where Ing represents the intake and Dig represents the digestibility. $\mathrm{FD}=F$. dimorpha, tot $=$ total diet (F. dimorpha and concentrate), and conc $=$ concentrate.

Digestible energy (DE) was estimated on the basis of organic matter content and digestibility of ash tree leaves on a basis of $18.66 \mathrm{MJ} / \mathrm{kg}$ of digested OM (NRC 1989). In consequence, the metabolizable energy (ME) concentration was calculated from the DE concentration using the NRC equation for $\mathrm{DE}$ to $\mathrm{ME}$ conversion $(\mathrm{ME}=0.82 \mathrm{DE})$.

\section{Data analysis}

Treatment of the participant survey was mainly qualitative, employing descriptive statistics to give a better understanding of the processes and practices associated with ash tree management; hence, considering proportions, or means and standard error. Data resulting from quantitative measurements were treated following GLM procedures, evaluated for normality distribution, and linear correlation coefficients were calculated after logarithmic transformation (Snedecor and Cochran 1957), and tested for significance.

For the digestion experiment, data on nutrient components, intake, and digestibility were combined across days, and analysed by one-way analysis of variance (ANOVA), with animal species included as the main effect. Animals were fed individually; therefore, individual sheep and goats were considered as the experimental units. Significant differences among means were detected using the protected LSD test (Steel and Torrie 1980). All data were processed with SPSS software (version 22).

\section{Results}

Pastoral uses of ash tree as fodder resource

\section{Use and management practices of ash tree resources}

Ash tree parklands are usually individually owned by farmer families. Only one stand of ash tree of the Ait M'Hamed Commune is a public forest managed by State foresters, but where access to livestock browsing and some cutting is informally allowed. Flocks start browsing ash tree leaves sporadically in April when leaves are young and soft; goats' productivity is enhanced at the beginning of this season, according to $56 \%$ of interviewees. Nonetheless, although ash tree leaves are browsed occasionally year-round when sheep and goats find them on the rangelands, the main period of pastoral 
use of ash tree foliage is autumn, from late August until November, when cold rain starts and leaves fall. This period is critical in the forage calendar since overall forage availability is very low in the neighbouring rangelands. People daily climb chosen trees, previously pollarded four years before, cut regrowth branches with a hatchet, and lay them on the ground for direct browsing (Figure 2). Hence, available leaf biomass results from a four-year growth. They usually cut almost all the branches growing on the tree, sometimes amounting to more than 250 per tree. Depending on the number of available branches, a single tree can be pollarded entirely in one day or during several consecutive days, adjusting the number of branches cut daily to the size of the flock. The most vigorous and straight branches are sometimes only thinned out along a length of $3.5 \mathrm{~m}$, and will be cut in four more years in order to obtain calibrated poles (length $3.5 \mathrm{~m}$, diameter $8 \mathrm{~cm}$ ) for the purpose of building house roofs, as well as fodder on the four-year growth top of the branch. The flock is then brought up to the cutting site and directly browses on the cut leafy branches on the ground.

The number of branches cut daily depends mainly on the size of the flock $\left(R^{2}=0.71, p<0.001\right)$. In our measurements, the number of branches cut daily per head was 1.2, but significant differences were found between flocks receiving fresh alfalfa as feed supplement $(0.9$ branch/head $)$ or not (1.7 branches/head); the number of branches cut depended largely on the composition of the overall diet provided to livestock, and to a lesser extent on the availability of trees. No correlation was found between branches distributed per head and per day, and the number of ash trees owned $\left(R^{2}=0.12, p>0.05\right)$. Mean leaf biomass consumed per head was calculated as $270 \mathrm{gDM} /$ day $(\mathrm{SE}=61)$ for flocks without supplementary feed, and $150 \mathrm{gDM} / \mathrm{head}(\mathrm{SE}=37$ ) for flocks with alfalfa supplementation. Considering a mean live weight of 27 and 23 $\mathrm{kg}$ for ewes and goats, respectively, and a daily intake of $3 \%$ of live weight, percent contribution of ash tree to daily diet during autumn can broadly be estimated at between $20 \%$ and $35 \%$, depending on whether the animals' diet is supplemented with cultivated forage or not. Herders mentioned that at the end of this period, fallen senescent leaves are also highly sought after and consumed by small stock directly on the rangeland.

Our survey highlighted that tree exploitation and management of ash trees in this part of the High Atlas follows a very precise sequence. It encompasses, on single living trees, overlapping cutting cycles of four years in order to produce fodder foliage, associated with eight-year cycles for the purpose of producing poles. Sometimes, particularly vigorous poles are conserved in order to produce beams in about 30-year cycles.

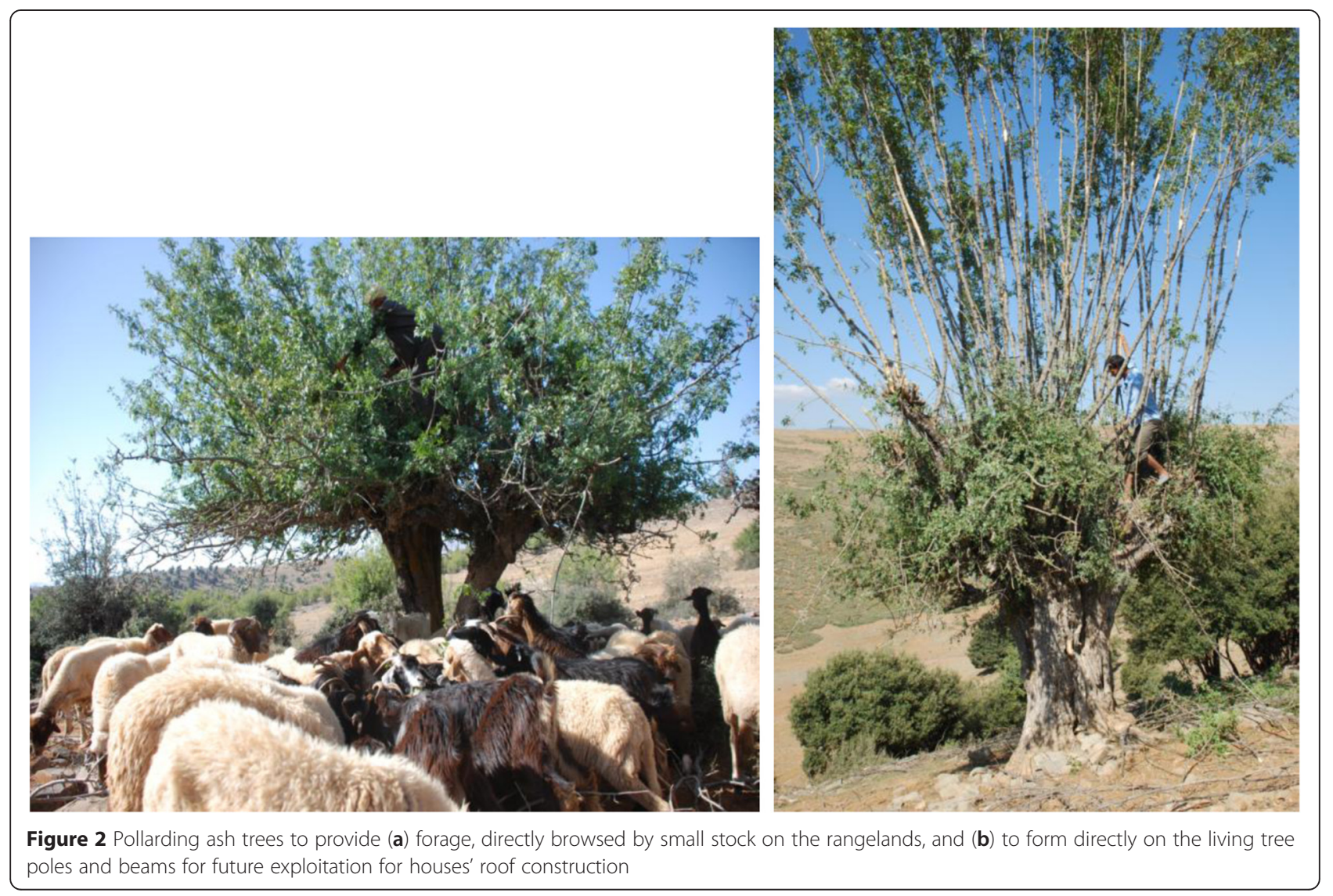




\section{Feeding calendar of the flocks}

On the basis of interviews and observations, we reconstructed a typical annual feeding calendar of the zone, as summarized in Figure 3. The ash tree is used as forage by occasional direct browsing in spring on bushy trees, but mainly made available to flocks directly on the rangeland by cutting leafy branches of large shaped trees in autumn. In spring, livestock seek in priority grasses and herbs, and only occasionally browse tree leaves. At the end of autumn, falling ash tree leaves constitute a forage resource directly consumed on the rangeland. Holm oak is also cut to a lesser extent, and enters the

\begin{tabular}{|c|c|c|c|c|c|c|c|c|c|c|c|c|}
\hline & Jan & Feb & March & April & May & June & July & Aug & Sept & Oct & Nov & Dec \\
\hline \multicolumn{13}{|c|}{ Grazing } \\
\hline \multicolumn{13}{|l|}{ local rangelands } \\
\hline \multicolumn{13}{|l|}{ Stubble fields } \\
\hline \multicolumn{13}{|l|}{ Altitude rangelands } \\
\hline \multicolumn{13}{|c|}{ Forage trees } \\
\hline \multicolumn{13}{|l|}{ Fraxinus dimorpha } \\
\hline \multicolumn{13}{|l|}{ Quercus ilex } \\
\hline \multicolumn{13}{|l|}{ Juniperus oxycedrus } \\
\hline \multicolumn{13}{|c|}{$\begin{array}{l}\text { Cutting season: branches, including fresh leaves are cut, and browsed directly on rangeland } \\
\text { Flocks occasionally eat fresh leaves directly on shrubby trees } \\
\text { Flocks eat fallen leaves }\end{array}$} \\
\hline \multicolumn{13}{|c|}{ Concentrates } \\
\hline \multicolumn{13}{|l|}{ Wheat bran - Barley } \\
\hline \multirow{2}{*}{\multicolumn{13}{|c|}{ Forage supplement }} \\
\hline & & & & & & & & & & & & \\
\hline \multicolumn{13}{|l|}{ Fresh alfafa } \\
\hline \multicolumn{13}{|l|}{ Straw, dry grass and } \\
\hline other supplements & & & & & & & & & & & & \\
\hline $\begin{array}{l}44 \% \text { of interviewe } \\
\text { supplements like sa }\end{array}$ & & netto, & Iry alfafa, & & ement & $30 \%$ & $\mathrm{aw}, 1$ & 7 dry & ass an & & & \\
\hline
\end{tabular}


forage calendar of the flock according to a different temporal pattern, due to its evergreen foliage. It represents the basis of winter diet when snow covers the ground. When available, Juniperus oxycedrus is also cut for feeding flocks, but only during a limited period in spring when new growth leaves are soft. When juniper leaves become thick, they are reputed to occasionally cause miscarriage in ewes. Hence, associated with range grass resources, tree foliage constitutes a critical source of forage during almost the whole year as basic diet, sometimes supplemented by cultivated forage or subproducts. It is also worth noting the temporal complementarity of the different tree fodder resources during the annual feeding process.

\section{Farmers' assessment of the ash tree as forage}

The ash tree is considered by locals as the highest quality tree fodder resource of the region, equivalent to good hay. All farmers mentioned that ash leaf consumption by goats enhanced goat productivity. More specifically, they reported an increase in both body reserves and milk production in $79 \%$ of cases, in body reserves in only $11 \%$, and in milk production in $10 \%$. Only $32 \%$ farmers mentioned a notable positive impact in sheep.

Different properties are locally attributed to ash tree forage. For $65 \%$ of the interviewees, ash tree forage causes diarrhoea in sheep in spring when the leaves grow. Diarrhoea occurs for about two weeks and then stops. For most herders, this diarrhoea is not considered as harmful: on the contrary, it is thought to 'clean' the digestive tract of livestock after winter. This observation was also mentioned by Bourbouze and Donadieu (1987), and supported by the chemical spectrum of ash trees in general, with the presence of phenols and coumarin (Kostova and Lossifova 2007).

\section{Nutritive value for sheep and goats of ash tree foliage in autumn \\ Chemical composition}

Chemical composition of ash tree leaves is summarized in Table 1. Ash tree leaves present a generally interesting chemical spectrum for use as forage in extensive livestock systems. The total parietal constituents were relatively low for tree forage, with an NDF content of $321 \mathrm{~g} / \mathrm{kgDM}$, and less than $100 \mathrm{~g} / \mathrm{kgDM}$ of lignin. Crude protein content, though relatively low $(83.5 \mathrm{~g} / \mathrm{kgDM})$, was above the threshold level of $75 \mathrm{~g} / \mathrm{kgDM}$, considered as the minimum $\mathrm{CP}$ concentration requirement for livestock maintenance.

Results of the secondary compound screening are shown in Table 2. Tannic compounds and coumarins represent the main families occurring in ash tree leaves.

The appearance of a dark green colour after adding ferric salt indicates the presence of non-hydrolyzed
Table 1 Nutrient composition of F. dimorpha foliage in autumn (October)

\begin{tabular}{lc}
\hline Components & \\
\hline DM (g/kg FM) & $544 \pm 23.0$ \\
OM (g/kg DM) & $931 \pm 36.2$ \\
MM (g/kg DM) & $69.1 \pm 1.8$ \\
CP (g/kg DM) & $83.5 \pm 4.1$ \\
NDF (g/kg DM) & $321.1 \pm 12.3$ \\
ADF (g/kg DM) & $252.9 \pm 10.1$ \\
ADL (g/kg DM) & $97.7 \pm 6.9$
\end{tabular}

$F M$ fresh matter, $D M$ dry matter, $O M$ organic matter, $M M$ mineral matter, $C P$ crude protein, NDF Neutral Detergent Fibre, ADF Acid Detergent Fibre, $A D L$ Acid Detergent Lignin

condensed tannins, or catekic tannins derived from catekols and proanthocyanidols. Tannins are more abundant in leaves than in seeds, which confirms the traditional use of ash tree leaves to dye wool dark grey. Coumarins are more abundant in leaves $(0.42 \mathrm{mg} / \mathrm{g}$ of pulverized leaves) than in seeds $(0.42 \mathrm{vs} 0.09 \mathrm{mg} / \mathrm{g}$ of pulverized material, respectively, $p<0.001)$. Further studies will need to be performed in the future to determine concentrations and assess the physiological properties more precisely.

\section{Digestion trial}

Total intake and digestibility for goats and sheep fed ash tree leaves are shown in Table 3. Values of DM intake found here indicated an average consumption of $3.2 \% \mathrm{LW}$ and $2.9 \% \mathrm{LW}$ in goats and sheep, respectively.

DMD of ash tree leaves is high for ligneous forage (69.5\% and $67.5 \%$ for goats and sheep, respectively). No differences in digestion coefficients (DM, OM, NDF, $\mathrm{ADF}$ ) were found between sheep and goats, except for $\mathrm{CP}$ and to a lesser extent Acid Detergent Lignin (ADL).

Ash tree leaf intake for the various digestible nutriments presented significant differences between goats and sheep. Their respective intake per metabolic weight unit $\left(\mathrm{kg}^{0.75}\right)$ was significantly different for DDM (57.1 vs $47.7 \mathrm{~g}$ ), DOM (37.3 vs $30.3 \mathrm{~g}$ ), and DCP (2.6 vs $1.6 \mathrm{~g}$ ).

ME intake amounted to $119 \%$ and $67 \%$ in goats and sheep, respectively, of the ME requirements for maintenance $\left(0.48\right.$ and $0.7 \mathrm{MJ} / \mathrm{kgBW}^{0.75}$, respectively, in goats and sheep, NRC 1989), while CP requirements $\left(5.6 \mathrm{~g} / \mathrm{kgBW}^{0.75}, \mathrm{NRC} 1989\right)$ were covered to levels of only $48 \%$ and $32 \%$ in goats and sheep, respectively.

\section{Discussion}

Ash tree foliage - a critical component of the feeding system

The forage calendar reconstituted here puts the emphasis on the complementarity of diversified forage resources, in time and space, that is usually the sustainability pillar of 
Table 2 Secondary compound screening in F. dimorpha leaves and seeds

\begin{tabular}{lllllll}
\hline & Alkaloids & Flavonoids & Terpenes and sterols & Tannins & Saponins & Coumarins \\
\hline Seeds & - & - & + & ++ & - & + \\
Leaves & - & - & + & ++++ & - & +++ \\
\hline
\end{tabular}

-: no reaction; + to +++ : low to high presence

low-input pastoral systems (Bollig 2006; Genin et al. 2012). It highlights the keystone place of tree foliage in this system, even though this type of forage resource is reputed to present several limitations for animal nutrition. The interests and limitations of fodder tree exploitation have been reviewed in the literature (Paterson et al. 1998); they take different forms depending on whether trees are planted or exploited from natural establishment. The lack of knowledge on economically and ecologically sustainable tree management is also pointed out (Smith et al. 2012). However, there is general consensus regarding the interest of fodder trees for the ecosystem services and goods they can provide, particularly for dry areas and low-input livestock farming systems (Le Houérou 2006).

Ash tree foliage is made available to flocks at the beginning of autumn, a period where grasses and herbs have already dried up or have been mostly consumed. Fodder resources from ash tree in autumn, and holm oak in winter, hence constitute an alternative resource to herd mobility, which is usually considered mandatory in similar situations in order to feed herds. The presence of this tree resource could have played a major role in the

Table 3 Intake and apparent digestibility of F. dimorpha leaves by goats and sheep

\begin{tabular}{lcccc}
\hline & Goat & Sheep & S.E.M. & Prob. \\
\hline DM intake (g/day) & & & & \\
Diet & 722.7 & 591.1 & 14.2 & $<0.001$ \\
Ash tree & 581.7 & 450.2 & 10.9 & $<0.001$ \\
DM diet digestibility & 0.712 & 0.703 & 0.036 & 0.29 \\
OM diet digestibility & 0.738 & 0.733 & 0.041 & 0.36 \\
Ash tree digestibility & & & & \\
Dry matter & 0.695 & 0.675 & 0.012 & 0.17 \\
Organic matter & 0.705 & 0.683 & 0.010 & 0.14 \\
Crude protein & 0.542 & 0.453 & 0.037 & 0.001 \\
Neutral Detergent Fibre & 0.538 & 0.523 & 0.034 & 0.21 \\
Acid Detergent Fibre & 0.462 & 0.473 & 0.026 & 0.38 \\
Acid Detergent Lignin & 0.297 & 0.264 & 0.012 & 0.013 \\
Ash tree intake (g/kgBW & & & & \\
Dry matter & & & & \\
Digestible OM & 57.1 & 47.7 & 2.24 & $<0.001$ \\
Digestible CP & 37.4 & 30.3 & 1.89 & $<0.001$ \\
Estimated ME intake (MJ/kgBW0.75) & 0.57 & 0.47 & & $<0.001$ \\
\hline
\end{tabular}

historic sedentarization of this nomad society. Data related to livestock browsing on rangelands reported in the literature emphasize the proportion of tree foliage in the diet of animals, rather than the biomass actually consumed. Petit and Mallet (2001) indicated that tree leaves can constitute more than $60 \%$ of the diet of cattle in August in south-west Burkina Faso. Practices involved in this case to make fodder foliage available to livestock did not match the specific cycle of harvesting we describe here, but were rather based on tree species choices and on the perceived immediate leaf availability. We did not find in the literature detailed data on foliage biomass extracted per tree. Slotte (2001), on the basis of historical records, provided estimations on amounts of leaf sheaves consumed yearly by Swedish livestock in the 19th century, but at the farmstead or regional level. However, in many parts of the world, tree foliage plays a role support for critical periods, as found in this study. This function is usually underestimated by academics, but is essential for enhancing the resilience of farming systems (Dawson et al. 2014).

\section{Ash tree foliage, a good forage for low-input livestock farming systems}

Chemical composition values and digestion coefficients obtained in the present study are in phase with reported data about the relatively good nutritional value of different ash tree species as forage in the Mediterranean region for ruminants (Masson and Decaen 1980; Papachristou 1996). Fibre fractions of $F$. dimorpha present values similar to mulberry leaves (Morus alba), usually presented as a high potential fodder alternative for animal production (Kandylis et al. 2009). The crude protein content is relatively low compared to other ash tree species referred to in the literature (Masson and Decaen 1980, Papachristou 1996, Papachristou et al. 1999; Masson and Decaen 1980). However, the dates of plant collection occurred in this study later in the season, with leaves tending toward senescence.

The presence of tannins and coumarin in leaves confirms previous studies on the general chemical spectrum of species from the genera Fraxinus (Kostova and Lossifova 2007). The concentrations and dynamics of these compounds will need to be determined in further studies. Papachristou (1996) reported concentrations of 57 and $18.1 \mathrm{mg} / \mathrm{gDM}$ of phenols and tannins, respectively, in Fraxinus olmus leaves in the fall. 
With regard to intake, values found in this study showed a significantly higher consumption by about $20 \%$ in goats than in sheep, and are within the mean of the range found by McCammon-Feldman et al. (1981) in their report of worldwide studies on goat intake. Papachristou (1996) also reported higher consumption of browses in goats compared to sheep, but mentioned that these discrepancies tended to disappear as the quality of the forage improved.

Concerning digestibility, the apparent digestibility coefficients of ash tree leaves were estimated here by difference, and did not account for possible interactions with the supplementary feed. Hence, they should be viewed with caution, since several authors mentioned the associative effects between forages and concentrates, and their consequences for feed utilization (Dixon and Stockdale 1999). However, authors such as Nastis and Malechek (1981) and Meuret (1988) showed a low increase in digestion coefficient due to a slight dietary supplementation for goats consuming tree foliage (1\% to $3 \%$ of variation). Results of this study showed higher values of above 10 points for $F$. dimorpha, compared to those obtained for Fraxinus olmus by Papachristou (1996), which supports the assertion of the local peasants that this species constitutes very good forage, compared to other locally available fodder trees. Local herders also mentioned that Fraxinus excelsior, also found in this region after being introduced during the French colonization, is far less strongly preferred by sheep and goats than $F$. dimorpha, due to a more bitter taste.

Differences between sheep and goats in the apparent digestibility of forage constituents were found only for $\mathrm{CP}$ and $\mathrm{ADL}$. For $\mathrm{CP}$, data reported here are in agreement with those of Salem et al. (2006) for different tree foliage digestibility, as well as those of Papachristou (1996), and tend to confirm the apparently greater ability of goats to digest likely combined protein-tannin complexes. Differences in ADL digestion coefficients between sheep and goats support Howe's suggestion that goats may have a mechanism to attenuate the undesirable effects of lignin (Howe et al. 1988). These data also tend to support the findings of Rogosic et al. (2006), who argued that the usually mentioned digestive superiority of goat diminishes as the nutritive value of forage increases, and becomes non-significant for medium- to good-quality forage. However, while ash tree OMD was merely the same in goats and sheep, it is noteworthy that the quality of DM intake was different between these two species since refusals were significantly more ligneous-focused for sheep than for goats. This difference is illustrated by the physical aspect of refusals found in sheep and goats (Figure 4).
Compared to sheep, the superior ability of goats to valorize ash tree foliage seems primarily due to their higher ingestion capacity than to a better ability to digest ash tree leaves per se.

\section{Traditional Ecological Knowledge (TEK) associated with refined practices of ash tree management}

The traditional ash tree management system described here has much to contribute for rediscovering and designing schemes for the multipurpose use of living trees for sustainable agroforestry systems, which are today the focus of increasing interest, and not only in developing countries (Nair and Garrity 2012, Smith et al. 2012). This method of exploiting living trees on the basis of a sophisticated rotation system is poorly documented, and there is a real need to better understand the richness of traditional practices locally implemented throughout the world. Mabey (1996) reported a simpler cutting system of F. excelsior in Britain, on a 10-year rotation basis, in order to obtain ash poles of highly versatile raw material. Charlton et al. (2003) also mentioned similar rotations for the exploitation of New Zealand trees as fodder source, associating pollarding and coppicing.

As observed in several parts of the world (Berkes et al. 2000; Singh et al. 2015), Berber peoples have developed profound ecological knowledge of the tree biology and opportunistic techniques for taking advantage of them (Genin and Simenel 2011). Pollarding techniques, overlapping cycles of use depending on the type of resources to be extracted, (associated with tree regeneration management techniques consisting of building stone walls around small trees until they become defensible, and favouring twig anastomosis for enhanced tree productivity (Genin and Alifriqui, in press) reflect a real alternative vision of a sound sustainable system of tree and forest management. This form of exploiting living trees provides evidence of human adaptation to the environment and a legacy of traditional knowledge and management systems. Peoples have shaped their home territory through their selection and manipulation of individual trees, and by modifying ecosystems (Turner et al. 2009). They thus produce cultural landscapes, of which the structure and functioning play a role in enhancing and securing their livelihood. This perception of making use of parts of a tree while keeping it alive constitutes another perspective of sound forest management, very different from the classic academic one. Its achievement also requires profound knowledge based on detailed biological and ecological understanding, calling for interconnected patrimonial and resilience approaches (Auclair et al. 2011). 


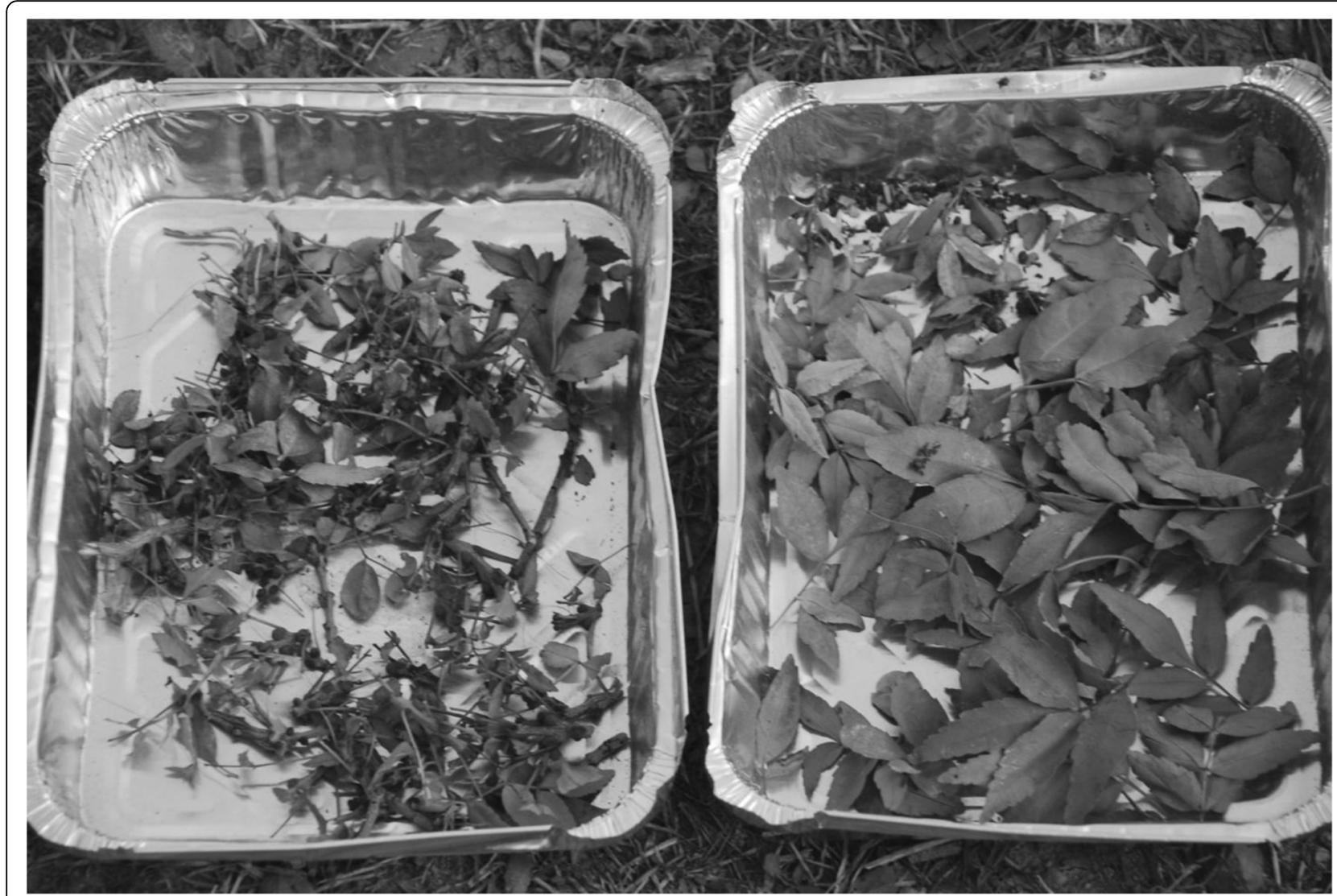

Figure 4 Differences in physical structure of ash tree refusals in sheep (left) and goats (right)

\section{Conclusion}

One of the most important concerns when dealing with the sustainability of low-input livestock farming systems is to be in phase with the seasonal variations of forage resources which are directly available on the rangelands. In dry mountain environments such as the Moroccan High Atlas, trees found in wooded ranges are an integrated part of the forage calendar of small ruminant flocks, since they offer forage at critical periods of low availability of standing grasses and herbs. Practices involved in the management of ash tree resources include highly sophisticated sequences, and reflect an intimate knowledge of the biology of these resources. Shaped ash trees, cyclically and rigorously pollarded and pruned, play a role in shaping a cultural landscape that is closely related to livestock production for the better valorization of the rare available resources in this mountainous area. These practices offer rich knowledge for envisaging alternate forms of pastoral production and rural forest management. Furthermore, the incorporation of TEK into formal research and extension services, as well as professional education curricula, may increase understanding among resource managers of the merit of local adaptations. TEK could also play a useful role in enhancement of scientific knowledge in phase with the renewed interest in multipurpose trees worldwide. Finally, TEK should be better taken into account for designing environmental and agricultural policies more in tune with the realities of local populations' lives. However, TEK is at present poorly recognized by forest and agriculture authorities in Morocco, who consider any cutting of living wood by local people as a legal offence. A better shared understanding of the perspectives that sound tree and forest management might offer policy-makers and local populations could be a basis for implementing more fully integrated environmental policies.

\section{Competing interests}

The authors declare that they have no competing interests.

\section{Authors' contributions}

DG designed the study, conducted the digestibility trial, and drafted the manuscript. CC conducted participant surveys, digestibility trial, and forage analyses. SM conducted field interviews in the Berber language, and phytochemical analyses. AA supervised forage analyses and revised the manuscript. MA designed the study, participated in the field survey, and revised the manuscript. All authors read the manuscript and agreed with its content. 


\section{Acknowledgements}

Research was carried out and partly funded within the collaborative structure: Laboratoire Mixte International MEDITER (Terroirs méditerranéens), and by the research programme MED-INN-LOCAL (Local Innovations in Mediterranean Landscapes) supported by the French National Research Agency (ANR-12-TMED-0001). Special thanks is due to Mohamed Izaghaghrine and his family who welcomed us and allowed us the possibility to conduct digestion trials in his farm, and particularly to Hassan for his dexterity to climb on trees and solve the small day-to-day harassments. Our sincere thanks also go to Saïd Oughzif for his patience to translate in Berber our questions, and to Peoples of the Commune of Ait M'Hamed for having spent time with us. Many thanks to the staff of the Animal Production Laboratory of the Hassan II Institute of Agronomy and Veterinary Medicine, Rabat, and of the Phytochemistry Laboratory of Cadi Ayyad University, Marrakesh, for their assistance. Finally, Mickael Paul revised the English wording.

\section{Author details}

'IRD and Aix-Marseille Université, Laboratoire Population, Environnement, Développement, UMR151, Marseille, France. ${ }^{2}$ SUPAGRO, 30 rue de la charpenterie, 45000 Orléans, France. ${ }^{3}$ University Cadi Ayyad, Faculté des sciences Semlalia, Marrakesh, Morocco. ${ }^{4}$ Institut Agronomique et Vétérinaire Hassan II, Département de productions animales, Rabat, Morocco. ${ }^{5}$ Department of Ecology, Université Cadi Ayyad, Faculté des sciences Semlalia, Marrakesh, Morocco. ${ }^{6}$ Department Environment \& Ecology. Faculté Semlalia, Université Cadi Ayyad, Marrakesh, Morocco.

Received: 3 February 2016 Accepted: 5 May 2016 Published online: 08 June 2016

\section{References}

AOAC. 1990. Official methods of analysis, 15th ed. Arlington: Association of Official analytical Chemists.

Arnold, J.E., and P.A. Dewees. 1997. Farms, trees \& farmers. Responses to agricultural intensification, 292. London, United Kingdom: Earthscan Publ. Ltd.

Auclair, L., P. Baudot, D. Genin, B. Romagny, and R. Simenel. 2011. Patrimony for resilience: Evidence from forest Agdal in Moroccan High Atlas. Ecology and Society 16:24.

Berkes, F., J. Colding, and C. Folke. 2000. Rediscovery of traditional ecological knowledge as adaptive management. Ecological Applications 10(5): 1251-1262. doi:10.1890/1051-0761(2000)010[1251:ROTEKA]2.0.CO;2.

Biernacki, P., and D. Waldorf. 1981. Snowball sampling. Sociological Methods and Research 10:141-163.

Boffa, J.M. 1999. Agroforestry parklands in sub-Saharan Africa, 34. Roma, Italy: FAO Conservation guide. http://www.fao.org/docrep/005/×3940e/×3940e00.htm. Accessed 24 July 2014.

Bollig, M. 2006. Risk management in a hazardous environment: A comparative study of two pastoral societies. N-Y, USA: Springer.

Bourbouze, A., and O. Donadieu. 1987. Livestock farming system on rangelands in Mediterranean regions, 1-88. Montpellier: Options Méditerranéennes, série études, CIHEAM. In French.

Bourbouze, A., and A. El Aïch. 2005. Goat breeding in the argan tree: Conflictual use of a territory. Cahiers d'Agriculture 14: 447-453 (in French).

Charlton, J.F.L., G.B. Douglas, B.J. Wills, and J.E. Prebble. 2003. Farmer experience with tree fodder. New Zealand Grassland Research and Practice Series 10:7-15.

Dawson, I.K., S. Carsan, S. Franzel, R. Kindt, P. van Breugel, L. Graudal, J.P.B. Lillesø, C. Orwa, and R. Jamnadass. 2014. Agroforestry, livestock, fodder production and climate change adaptation and mitigation in East Africa: issues and options. ICRAF Working Paper No. 178. Nairobi: World Agroforestry Centre. http://dx.doi.org/10.5716/WP14050.PDF.

Dixon, R.M., and R. Stockdale. 1999. Associative effects between forages and grains: Consequences for feed utilization. Australian Journal of Agricultural Research 50:757-774.

Etienne, M. 1996. Western European silvopastoral systems. Paris: INRA Editions.

Faye, M.D., J.C. Weber, B. Mounkoro, and J.M. Dakouo. 2010. Contribution of parkland trees to farmers' livelihoods: A case study from Mali. Development in Practice 20:428-435.

Genin, D., and R. Simenel. 2011. Endogenous Berber forest management and the shaping of rural forests in Southern Morocco: Implications for shared forest management options. Human Ecology 39:257-269.
Genin, D., B. Fouilleron, and L. Kerautret. 2012. A well moderated tempo: Place and role of Agdals in livestock systems in the Ayt Bouguemez valley, Morocco. In Agdal: A social ecological patrimony of the Moroccan Atlas, ed. L. Auclair and M. Alifriqui, 411-434. Rabat, Morocco: IRCAM Editions (in French).

Genin, D., Y. Aumeerudy-Thomas, G. Balent, and R. Nasi. 2013. The multiple dimensions of rural forests: Lessons from a comparative analysis. Ecology and Society 18:27.

Genin, D., and M. Alifriqui. (In press). Functional Terroirs' and functions of territories: Two examples of rural forests in the Moroccan Central High Atlas. In 'Terroirs', tourism and rural patrimonies: Opportunities for local development in the XXIth century?, eds. Berriane, M. and G. Michon. Marseille: IRD Editions. (In French).

Howe, J.C., T.N. Barry, and A.I. Popay. 1988. Voluntary intake and digestion of gorse (Ulex europaeus) by goats and sheep. Journal of Agricultural Science Cambridge 111:107-114.

Kandylis, K., I. Hadjigeorgiou, and P. Harizanis. 2009. The nutritive value of mulberry leaves (Morus alba) as a feed supplement for sheep. Tropical Animal Health Production 41:17-24.

Kostova, I., and T. Lossifova. 2007. Chemical components of Fraxinus species. Fitoterapia 78:85-106.

Le Houérou, H.N. 2006. Agroforestry and sylvopastoralism: The role of trees and shrubs in range rehabilitation and development. Sècheresse 17:343-348.

Mabey, R. 1996. Flora Britannica: The definitive new guide to Britain's wild flowers, plants and trees. London, United Kingdom: Sinclair Stevenson.

Masson, C., and C. Decaen. 1980. Chemical composition and nutritive value of young regrowth of poplar (Populus) and ash tree (Fraxinus). Annales de Zootechnie 29:195-200 (in French).

McCammon-Feldman, B., P.J. Van Soest, P. Horvath, and R.E. Mc-Dowell. 1981 Feeding strategy of the goat. Ithaca, USA: Cornell International Agriculture Mimeograph 88, Cornell University.

McGregor, H.V., L. Dupont, W. Stuut, and H. Kuhlmann. 2009. Vegetation change, goats and religion: A 2000-year history of land use in southern Morocco. Quaternary Science Reviews 28: 1434-1448.

Meuret, M. 1988. Feasibility of in vivo digestibility trials with lactating goats browsing fresh leafy branches. Small Ruminant Research 1: 273-290.

Msou, S. 2013. Dimorph ash tree: Foraging aspects and traditional uses in the Moroccan High Atlas agroforestry systems. [Master Thesis], 67. Marrakesh: Cadi Ayyad University.

Nair, P.K.R., and D.P. Garrity. 2012. Agroforestry: The future of global land use. Amsterdam, The Netherlands: Springer.

Narvaez, N., A. Brosh, M. Mellado, and W. Pittroff. 2011. Potential contribution of Quercus durata and Adenostoma fasciculatum supplemented with Medicago sativa on intake and digestibility in sheep and goats. Agroforestry Systems 83:279-286.

Nastis, A.S., and J.C. Malechek. 1981. Digestion and utilization of nutrients in oak browse by goats. Journal of Animal Science 53: 283-290. doi:10.2134/jas1981. 532283x.

NRC. 1989. National Research Council. Nutrient requirements of dairy cattle. Washington: National Academy Press. $6^{\text {th }}$ revised Edition.

Papachristou, T.G. 1996. Intake, digestibility and nutrient utilization of oriental hornbeam and manna ash browse by goats and sheep. Small Ruminant Research 23:91-98.

Papachristou, T.G., P.D. Platis, V.P. Papanastis, and C.N. Tsiouvaras. 1999. Use of deciduous woody species as a diet supplement for goat grazing Mediterranean shrublands during the dry season. Animal Feed Science and Technology 80:267-279.

Paterson, R.T., G.M. Karanja, O. Roothaert, O.Z. Nyaata, and C. Kariuki. 1998. A review of tree fodder production and utilization within smallholder agroforestry systems in Kenya. Agroforestry Systems 41:181-199.

Petit, S. 2003. Parklands with fodder trees: A Fulbe response to environmental and social changes. Applied Geography 23:205-225.

Petit, S., and B. Mallet. 2001. Pollarding ligneous trees: Detail of a pastoral practice. Bois et Forêts des Tropiques 4:35-45 (in French).

Petit, S., and C. Watkins. 2004. Forgotten peasant practices: Tree pollarding in Great Britain. Etudes rurales 169: 197-214 (in French).

Robertson, J.B., and P.J. Van Soest. 1981. The detergent system in analyses. In The analysis of dietary fiber in food, ed. W.P.T. James and O. Theander, 123. New York: Marcel Dekker Editions.

Rogosic, J., J.A. Pfister, F.D. Provenza, and D. Grbesa. 2006. Sheep and goat preference for and nutritional value of Mediterranean maquis shrubs. Small Ruminant Research 64:169-179. 
Salem, A.Z.M., M.Z.M. Salem, M.M. El-Adawy, and P.H. Robinson. 2006. Nutritive evaluations of some browse tree foliages during the dry season: Secondary compounds, feed intake and in vivo digestibility in sheep and goats. Animal Feed Science and Technology 127: 261-267.

Singh, R.K., A. Singh, S.T. Garnett, K.K. Zander, D.K. Lobsang, and D. Tsering. 2015 Paisang (Quercus griffithii); a keystone tree species in sustainable agroecosystem management and livelihoods in Arunachal Pradesh, India. Environmental Management 55: 187-204

Slotte, H. 2001. Harvesting of leaf-hay shaped the Swedish landscape. Landscape Ecology 16: 691-702.

Smith, J., B.D. Pearce, and M.S. Wolfe. 2012. A European perspective for developing modern multifunctional agroforestry systems for sustainable intensification. Renewable Agriculture and Food Systems 27: 323-332. doi:10. 1017/\$1742170511000597.

Snedecor, G.W., and W.G. Cochran. 1957. Méthodes statistiques, 6th ed. Ames: The lowa State University Press.

Solorio Sanchez, F.J., and B. Solorio Sanchez. 2002. Integrating tree fodder into animal production systems in the Tropics. Tropical and Sub-tropical Agroecosystems 1: 1-11.

Steel, R.G.D., and J.H. Torrie. 1980. Principles and procedures of statistics, 2nd ed. New York: McGraw-Hill.

Thapa, B., D.H. Walker, and F.L. Sinclair. 1997. Indigenous knowledge of the feeding value of tree fodder. Animal Feed Science and Technology 67: 97-114.

Thiebault, S. 2005. Supply of tree fodder in animal husbandry since the Neolithic. Anthropozoologica 40(1): 95-108 (in French).

Turner, N.J., Y. Ari, F. Berkes, I. Davidson-Hunt, Z. Fusun Ertug, and A. Miller. 2009. Culturally modified trees: An international perspective. Journal of Ethnobiology 29: 237-270.

Van Soest, P.J., J.B. Robertson, and B.A. Lewis. 1991. Methods for dietary fibre, neutral detergent fibre, and nonstarch carbohydrates in relation to animal nutrition. Journal of Dairy Science 74: 3583-3597.

\section{Submit your manuscript to a SpringerOpen ${ }^{\circ}$ journal and benefit from:}

- Convenient online submission

- Rigorous peer review

- Immediate publication on acceptance

- Open access: articles freely available online

- High visibility within the field

- Retaining the copyright to your article

Submit your next manuscript at $>$ springeropen.com 